\title{
Practice of use of diapers in hospitalized adults and elderly: cross-sectional study
}

\author{
Prática do uso de fraldas em adultos e idosos hospitalizados: estudo transversal \\ Práctica del uso de pañales en adultos y ancianos hospitalizados: estudio transversal
}

\section{Graziele Ribeiro Bitencourt', Luise de Almeida Ferreira Alves', Rosimere Ferreira Santana'}

'Universidade Federal Fluminense, Postgraduate Program in Nursing. Niterói, Rio de Janeiro, Brazil.

\section{How to cite this article:}

Bitencourt GR, Alves LAF, Santana RF. Practice of use of diapers in hospitalized adults and elderly: cross-sectional study. Rev Bras Enferm [Internet]. 2018;71(2):343-9. DOI: http://dx.doi.org/10.1590/0034-7167-2016-0341

\section{Submission: 09-11-2016 Approval: 02-05-2017}

\section{ABSTRACT}

Objective: analyze the practice of use of diapers in adults and elderly in hospital. Method: observational cross-sectional study, with a sample of 105 participants assigned according to the data collection period, from September 2013 to January 2014, in the surgical clinic wards in a University Hospital. Results: it was observed that $38 \%$ of the 105 participants of the study did not need the use of diapers. $18 \%$ used it because they were disabled and $16 \%$ had their cognitive system damaged. As they were hospitalized, it was identified that $51.4 \%$ of patients were there ranging from 02 to 10 days, and $60 \%$ used diapers for the same period. It is also identified that long term urinary catheter $(24.8 \%)$, as technology associated to diapers in the urinary control and to pressure ulcers (12.4\%), being the main complication. Conclusion: the use of diapers did not have specific criteria to be selected. For this, it was proposed an "Evaluation Scale of Diapers Use in Adults", as for indication as for its monitoring to help the study transposal for the nursing practice.

Descriptors: Adults Diapers; Geriatric Nursing; Nursing Care; Biomedical Technology; Elderly.

\section{RESUMO}

Objetivo: analisar a prática do uso de fraldas em adultos e idosos no cenário hospitalar. Método: estudo do tipo observacional, transversal, com amostra por conveniência de 105 participantes, alocados segundo o período de coleta dos dados, de setembro de 2013 a janeiro de 2014, nas enfermarias de clínica cirúrgica de um Hospital Universitário. Resultados: observou-se que 38\% dos 105 participantes do estudo não apresentavam motivos para usar fraldas. $18 \%$ utilizavam devido à mobilidade prejudicada e $16 \%$ por cognitivo prejudicado. No tempo de internação, identificou-se 51,4\% dos pacientes estavam internados de 02 a 10 dias, e $60 \%$ utilizavam fraldas pelo mesmo período. Identifica-se ainda o cateter vesical de demora (24,8\%), como tecnologia associada às fraldas no controle urinário e, a úlcera por pressão (12,4\%), como complicação principal. Conclusão: o uso de fraldas se mostrou com critérios inespecíficos na seleção do seu uso. Por isso, propõe-se uma "Escala de Avaliação do Uso das Fraldas para Adultos" tanto para indicação, como para o seu acompanhamento, para auxiliar na transposição do estudo para a prática de enfermagem.

Descritores: Fraldas para Adultos; Enfermagem Geriátrica; Cuidados de Enfermagem; Tecnologia Biomédica; Idoso.

\section{RESUMEN}

Objetivo: analizar la práctica del uso de pañales en adultos y ancianos en el escenario hospitalario. Método: estudio del tipo observacional, transversal, con muestra por conveniencia de 105 participantes, asignados según el período de recolección de los datos de septiembre de 2013 a enero de 2014, en las enfermerías de clínica quirúrgica de un Hospital Universitario. Resultados: fue observado que el 38\% de los 105 participantes del estudio no presentaban motivos para usar pañales. El $18 \%$ utilizado fue debido a la movilidad perjudicada y el $16 \%$ al cognitivo perjudicado. En el tiempo de la hospitalización, fue identificado que el 51,4\% estaban hospitalizados de 02 a 10 días y el 60\% utilizaban pañales por el mismo período. Además, identificase el catéter vesical de demora (24,8\%) como tecnología asociada a los pañales en el control urinario y la úlcera por la presión $(12,4 \%)$ como complicación principal. Conclusión: el uso de pañales se mostró con criterios inespecíficos en la selección de su uso. Por eso se propone una "Escala de evaluación del uso de los pañales para adultos" tanto para indicación como para su acompañamiento, para auxiliar en la transposición del estudio para la práctica de la enfermería.

Descriptores: Pañales para Adultos; Enfermería Geriátrica; Cuidados de Enfermería; Tecnología Biomédica; Anciano.

\section{CORRESPONDING AUTHOR Graziele Ribeiro Bitencourt E-mail: gra_uff@yahoo.com.br}




\section{INTRODUCTION}

The incorporation of technologies entails the need for constant renewal of care practices ${ }^{(1)}$. The nurse needs theoreticalpractical foundations to help them when making a decision to judge clinically, by the adoption or not of new technologies ${ }^{(2)}$. Adult diapers are one of these technologies transposed to nursing practice without proper considerations of indication of use, time, process or appropriate products.

Adult diapers is the term identified in the literature as a descriptor in the databases, defined by the Virtual Health Library as "hygienic absorbents designed to be worn as underwear or pants paddings by adults". The definition of absorbents, by Medical Subject Headings / Mesh, intended to be used as underwear, pants or paddings, is presented by adults. However, in practice, the name of the popularized product is geriatric diaper, although it is not only used in the elderly.

In this context, diapers have the function of absorbing the urinary and / or fecal flow ${ }^{(3)}$. They should be indicated for adults and the elderly with incontinence or restrictions of severe mobilization, which are not possible to use aid utensils to control urinary and intestinal elimination. However, there is a gap in the literature on instruments that assist them in the evaluation of systematized criteria for a valid indication of diaper use. Hence, their adoption in nursing practice becomes commonplace and empirical ${ }^{(4)}$.

A Brazilian study aimed at evaluating the main technologies applied by nursing in urinary control identified that $42.3 \%$ of hospitalized adults and elderly patients used diapers, followed by external catheter drainage $(34.6 \%)$, intermittent catheterization (19.3\%) and suprapubic catheterization $(3.8 \%)^{(5)}$.

Another international study of systematic review identified as main strategies of urinary elimination control: the promotion of continence and urinary control. He pointed out behavioral training programs and the use of geriatric pads (pads), as the main measures of treatment of urinary incontinence, with a reduction of economic costs. Drug therapy, as a complement to combined behavioral training, has shown effective improvements in the short term. Thus, adaptations to the physical environment, and personnel training techniques may be necessary in the medium term to improve results ${ }^{(6)}$.

A household study showed that, among the various cost categories, absorbent materials were the most expensive, accounting for $63 \%$ of the total patient costs for the management of urinary incontinence. Of the majority, $84 \%$ were women, reported additional laundry loads (19\% of total costs) and $12 \%$ reported additional cleaning each week for urinary incontinence $(12 \% \text { of total costs) })^{(7)}$.

In the hospital environment, even not being an invasive practice, low costs compared to other technologies, its practice if it is disseminated in the daily routine, it trivializes and prevents to evaluate the risks often associated with the use of diapers. The literature reports as primary complications: incontinence-associated dermatitis (ICD), pressure sores (PS), pain and discomfort, and worsening of urinary incontinence $\mathrm{e}^{(7)}$. It also has risks associated with low self-esteem, in addition to increasing the risk of nosocomial infection ${ }^{(8)}$.
It is also known that incontinence has effects on the social and mental well-being of the elderly, and can significantly affect the worsening of the quality of life, reported in $81 \%$ of patients with urinary incontinence who reported sensations as: frustration, shame, worry, loss of self-confidence, anxiety and sadness, which were the most recurrent ${ }^{(9-10)}$.

The incontinence-associated dermatitis (ICD) is the main complications of indiscriminate diaper use. They consist of skin changes caused by a combination of factors: urine and stool irritation, maceration produced by moisture and local heat. Prolonged contact with the wet urine diaper enhances skin permeability to irritants as the $\mathrm{pH}$ of the environment, and enhances the activity of fecal proteases and lipases, which are the major irritants and are responsible for the changes ${ }^{(11-12)}$. Studies indicate a lower tolerance to friction and pressure in the diaper user population, leading to a higher risk of ulceration, discomfort and pain ${ }^{(13-14)}$.

Urinary tract infection is also at increased risk for diaper use, defined as altered urinary tract, and characterized by symptoms associated with the presence of bacteria in the urine ${ }^{(15)}$. The main microorganisms that trigger this condition are part of the transient flora of the perineum, which refers to the reflections related to the importance of intimate hygiene, and the self-care of patients in the use of diapers. These microorganisms may be represented by Streptococcus faecalis, Proteus mirabilis, Pseudomonas aeruginosa and Escherichia coli ${ }^{(16)}$.

In addition, there are studies about the perception of the nursing team in the diaper changes that describe it with a feeling of privacy invasion, and as a repetitive and stigmatized technique ${ }^{(17)}$.

As a result, daily use in hospital practices reflects the lack of proper care of the family - who before the hospitalization - did not make use of the nappies at home, but used them without proper transposition of hospital care to the home ${ }^{(18)}$.

On the other hand, the maintenance of the clean bed appears as a relevant factor for the individuals who suggest the use of diapers as a welfare promoter, conservative of autonomy, saver and promoter of tranquility to patients ${ }^{(4)}$. Due to motor limitations, the use of diapers may be considered necessary for individuals who feel more comfortable with less handling, and expect the diapers to prevent leakage in the bed, and decrease the frequency of changes. Elderly also report a way to facilitate the work of the nursing team, since it identifies itself as care dependents and - using this technology - reduces the requests to the staff, which increases their restriction in bed $^{(4)}$.

In this way, the gap is observed in protocols that encourage the making of decision, corroborating a scenario of heterogeneous patients making use of the diapers. From this, it is assumed that nurses do not present criteria for the choice of diaper use, as a strategy of urinary control in hospitalized adults and elderly. Therefore, this study aims at analyzing the practice of diaper use in adults and the elderly in the hospital setting.

\section{METHOD}

\section{Ethical aspects}

The study is in compliance with Resolution 510/16 and is approved by the Research Ethics Committee of the Medicinal School / Hospital Universitário Antônio Pedro on and, that 
participation was conditional on the signing of the informed consent form templates (ICFT) of each subject or his / her respective legal representative.

\section{Design, place of study and period of time}

The study presents a quantitative, cross-sectional, observational approach. Data were collected from September 2013 to January 2014 in the male and female wards of the surgical clinic of a large University Hospital in Rio de Janeiro.

\section{Population or sample; inclusion and exclusion criteria}

It is a convenience sample of 105 participants, allocated according to the period of data collection; who used diapers; of both genders; participants from 20 years of age up to 60 years of age were considered adults; and the elderly those from 60 years complete.

\section{Study protocol}

The data were collected, in a form-type instrument, constructed for this research with the variables: sociodemographic (age, gender, schooling); reason for current hospitalization (clinical, surgical, and orthopedic); reason for diaper use (impaired physical mobility, cognitive disorder and urinary incontinence), evaluated with the aid of standardized instruments; length of hospital stay (in days); diaper use time (in days); skin evaluation; and risk for pressure sore (NPUAP).

\section{Results analysis and statistic}

Validated instruments were already used to evaluate the variable, reason for diaper use. The Mini Mental State Examination (MMSE) contributed to the evaluation of cognitive impairment, considering cognitive impairment, scores lower than 18 out of the total of 30. The KATZ scale evaluated the physical mobility and activities of daily living, the degree of dependence and the scores from Index D, that is, those with Index D, E, F, G and 'other' show dependence on the elderly, especially with regard to 'going to the toilet' and 'continence'. For urinary incontinence, the International Consultation on Incontinence Questionnaire - Short Form (ICIQ / SF) was used. This instrument is composed of four questions that assess the frequency, severity and impact of urinary incontinence, as well as a set of eight self-diagnostic items related to the causes or situations of urinary incontinence experienced by patients. This is a simple, brief, self-administered questionnaire to quickly assess the impact of urinary incontinence (UI) on quality of life and qualify urinary loss of patients of both genders. It consists of four questions assessing the frequency, severity and impact of urinary incontinence, as well as a set of eight self-diagnostic items related to the causes or situations of urinary incontinence experienced by patients ${ }^{(19)}$. The assessment to determine the presence of incontinence dermatitis is basically clinical and lesions can be identified through skin characteristics such as: (1) persistent redness, (2) burning, (3) temperature increase, (4) presence or absence of blisters in regions susceptible to exposure to feces and urine and (5) lesion observed by loss of epidermis ${ }^{(20)}$.

After the data collection phase, the analysis was started from: 1) transcription data in Excel table; 2) presentation of the data in the form of descriptive statistics using the absolute and percentage frequency distribution; and 3) discussion of the findings.

\section{RESULTS}

The data obtained from the study participants identify how diaper practice occurs in adults and the elderly in the hospital.

Table 1 presents the characterization of the participants of diapers used in the study.

A predominance of females $(60.9 \%)$ was observed, ranging from 41 to 60 years old $(39.1 \%)$ and due to surgical hospitalization $(54.3 \%)$

Table 1 - Characterization of patients according to gender, age and reason for hospitalization $(\mathrm{N}=105), \mathrm{Ni}-$ terói, Rio de Janeiro state, Brazil, 2014

\begin{tabular}{lcc}
\hline Variables & $\mathbf{n}$ & $\mathbf{\%}$ \\
\hline $\begin{array}{l}\text { Gender } \\
\quad \text { Female }\end{array}$ & \\
$\quad$ Male & 64 & 60.9 \\
Age (years) & 41 & 39.1 \\
$20-40$ & & \\
$41-60$ & 14 & 13.3 \\
$61-80$ & 41 & 39.1 \\
$\quad \geq 81$ & 38 & 36.2 \\
Reason for hospitalization & 12 & 11.4 \\
$\quad$ Cirurgical (except orthopedic) & 57 & \\
$\quad$ Clinical & 29 & 54.3 \\
$\quad$ Orthopedic & 19 & 27.6 \\
Total $\quad 18.1$ \\
$\quad$
\end{tabular}

Table 2 - Distribution of diaper use by reason, time of hospitalization and use, other associated technologies and complications found ( $\mathrm{N}=105)$, Niterói, Rio de Janeiro state, Brazil, 2014

\begin{tabular}{lcc}
\hline Variables & $\mathbf{n}$ & $\mathbf{\%}$ \\
\hline Reason for the use of diaper & & \\
Use without a predetermined criteria & 40 & 38.0 \\
Mobility impairment & 19 & 18.0 \\
Cognitive impairment & 17 & 16.1 \\
Mobility and cognitive impairment & 16 & 15.2 \\
Urinary incotinence & 11 & 10.4 \\
Mobility, cognitive impairment and urinary incontinence & 02 & 1.9 \\
Diarrhea & 03 & 2.8 \\
Period of hospitalization (days) & & \\
O2 - 10 & 54 & 51.4 \\
$11-20$ & 31 & 29.5 \\
$21-30$ & 13 & 12.4 \\
$\geq 31$ & 07 & 6.7 \\
Use of diapers period (days) & & \\
02 - 10 & 63 & 60 \\
$11-20$ & 22 & 20.9 \\
$21-30$ & 13 & 12.4 \\
$\geq 31$ & 07 & 6.7 \\
Other associated technologies & & \\
Long term urinary catheter & 26 & 24.8 \\
External cateter & 05 & 4.8 \\
Primary complications & & \\
Pressure sores & 13 & 12.4 \\
Incontinence Associated- Dermatitis (IAD) & 09 & 8.6 \\
& & \\
& &
\end{tabular}


Table 2 shows the distribution of the reason for diaper use, time of hospitalization and diaper use, other associated technologies, and primary complications.

It was observed that of the 105 participants in the study, 38.0\% had no reason to use the diaper, that is, they had no motor, cognitive or urinary restriction, and even in the personal interview, they did not know how to correlate the reason for the use and refer be the routine of the institution. At the time of admission and use of the diaper, it was identified that $51.4 \%$ were hospitalized in the period of 02 to 10 days and $60 \%$ used diapers for the same period. It is also identified as other technologies associated with the use of diapers, the long term urinary catheter $(24.8 \%)$ and pressure ulcer $(12.4 \%)$, as more frequent complications.

\section{DISCUSSION}

The analysis of the use of diapers in adults and the elderly showed an unsystematic practice and, without considering the criteria of presence of urinary incontinence, cognitive disorder or impairment of mobility. In this way, patients can be exposed to complications such as urinary incontinence, skin sores and infections.

Pads are more effective in women, which are cited as the majority, in longevity and problems in urinary elimination, as in this study. This, due to the anatomical aspects, such as shortening of the urethra, deposition of collagen during menopause, which hinders the closure of the sphincters, as well as the reduction of estrogen ${ }^{(21)}$.

The difference in the products of choice for adult gender is still sparse, unlike that found with infant diapers. The choice of the female collector is according to the volume of urinary loss and the dependence of the woman on the availability of toilets. Additional devices are usually brought in personal bags to meet the needs of exchanges; thus, the woman's dependence relation with the use of these devices is evaluated according to the expected urinary loss during the 24-hour period ${ }^{(7)}$.

The literature points out the associated use of diapers on the pads or the absorbent test. It is a simple, non-invasive and effective method to assess urinary loss. The application of the pad test assists in the classification of incontinence as mild, moderate and severe, according to the loss of urine by weighing the inner absorbent. The technique does not necessarily reveal the total daily urinary loss of the patient, but allows quantifying the incontinence resulting from simulating exercises of the daily routine. The one-hour pad test has the advantage of speed and ease of execution, as well as low cost, high specificity and sensitivity, as well as the objective evaluation of the patient's complaints by a specialized professional ${ }^{(22)}$.

Unlike the literature found as the main causes of diaper use, the clinical lack of control of circulatory diseases, such as arterial hypertension, in this study, surgical causes were identified $^{(23)}$. It is thought that surgical patients should be healthy because they are hospitalized for the procedure and therefore should not use diapers. Two hypotheses can be inferred: the profile of the surgical clinic has changed, or the use of diapers in independent and capable people is common in the hospital routine.
For the most part, the age range of the study was between 41 and 60 years old, so that it did not show to be only dependent elderly, fragile and with severe losses in elimination ${ }^{(24)}$. However, $52.4 \%$ and $47.6 \%$ of the elderly (61 to 80 years of age) had a minimum difference of $52 \%$ when compared to adults (20-60 years), international studies ${ }^{(25)}$.

From this, it is recommended to evaluate some criteria to decide whether or not it is necessary to use the diapers and the indication of the appropriate products in each case, the size of the person and the loss eliminated. For use in adults, the use of Medium to Oversized Diapers is considered. The indication can be observed by the manufacturers, considering the weight and the measure, by tape measure of the abdominal perimeter of the adult or elderly. According to most manufacturers, size $M$ suits those with waist of 80 to $115 \mathrm{~cm}$ and weight of 40 to $70 \mathrm{~kg}$; for size G, those with 115 to 150 $\mathrm{cm}$ waist and 70 to $90 \mathrm{~kg}$; and for oversized size, those with a waist of 120 to $165 \mathrm{~cm}$ and a weight of over $90 \mathrm{~kg}^{(5)}$.

In addition, it is necessary to evaluate the number of diapers exchanged daily by the nursing team from the urinary loss in order to avoid complications. Studies evaluating hygienic products suggest that, the minimum exchange values should be at six-hourly intervals. That is, at least four daily exchanges should be performed regardless of the presence of elimination ${ }^{(26-27)}$.

In order to increase skin protection in changing diapers, there are products used after thorough cleansing that provide a protective barrier. Its distribution should occur in the most vulnerable regions such as perineal, inguinal and sacral, uniformly, coating a thin layer. On topical products, some authors suggest the concomitant use of occlusive moisturizers, whose function is to serve as a skin barrier for protection against irritants and moisture. Options include: 1) those protectors based on zinc oxide, dimethicone and pretolate and; 2) the acrylate liquids ${ }^{(28)}$.

The amount of product applied in the elderly should be higher than that applied in the elderly, as they have more skin folds due to the anatomical shape common to the female body, plus the application, also performed in the mucosal areas of the vagina. Although the amount used in the elderly was higher, excessive use was avoided by application, particularly in the vaginal region ${ }^{(28)}$.

The perineal environment can be altered by the frequency and type of incontinence and by the condition of the skin (inflammation, edema). The factors that impair the perineal region are hydration, $\mathrm{pH}$ of the urine or feces, and pathogens already present in the fecal content or in the microbiota of the skin. These should be investigated by the nursing team during diaper changes.

It is also necessary to evaluate the cognitive ability of the elderly to recognize the need to go to the toilet and ask for help when necessary, to understand the influence of this process and to support the severity of incontinence, and to increase the need for diapers. In the study, the average score of the Mini Mental State Examination was observed as an unsatisfactory score in relation to the cognitive ability in the groups. It is recommended to use this test to help quantify the cognitive impairment of the elderly. Thus, the condition of impaired 
cognition affects the ability of the elderly to indicate the need for elimination and thus, determines dependence ${ }^{(10)}$.

In order to evaluate the degree of motor capacity, the instrument that helped us decide from the impairment of mobility was the Katz index. Decreased functional capacity of the elderly occurs gradually, depending on the complexity. Initially, it develops with commitment, motor with reflex in the advanced daily activities of the life, followed by the instrumental activities and, finally, the basic daily activities of the life, generally linked to the self-care. A previous study suggests that the elderly, for the most part, associate the loss of dependence with the insertion of diapers during hospitalization, as the autonomous capacity, that is, the decision-making power over the still existing body, becomes gradually reduced in this period ${ }^{(4)}$.

From this, the hospitalization period occurred with a simultaneous interval to the use of the diapers. The decision to place a geriatric diaper on bedridden or semi-dependent patients is often controversial in some hospital practices. Since the stimulation to early ambulation would be indicated as a better strategy to promote urinary and intestinal eliminations, thus avoiding the use of diapers. The posture and decision require previous evaluations of the nurse, based on the family approach, structural issues of the hospital environment and, above all, accurate analysis of the installed urinary incontinence, including anamnesis and the physical examination of the patient ${ }^{(13)}$.

Thus, excessive use of diapers in hospitalization may be a consequence of the cancellation of other techniques or strategies to stimulate spontaneous elimination, such as the provision of urinals; scheduled disposal and monitoring of the toilet; and that if they were performed they could reduce the use of diapers by $50 \%{ }^{(29)}$.

Urinary incontinence determines the need for diaper use in the same way as its use in a person with spontaneously preserved elimination may lead to incontinence due to lack of stimulation in the control of eliminations. That is, the use of diapers in the presence of urinary incontinence can establish an indeterminate cycle of causality ${ }^{29)}$.

Another interesting fact was the association of the use of diapers to the long term urinary catheter. This, refers to a potent urinary elimination technology to increase the risk of hospital infection due to its invasive characteristic ${ }^{(30)}$. If the diapers are associated with the long term urinary catheter, it may increase an infectious risk by heating the skin, increasing the $\mathrm{pH}$, and presence of fecal contents. In addition, there may be discomfort due to the use of two distinct and uncomfortable associated technologies ${ }^{(11)}$. However, no studies were found to associate these elimination control resources or to correlate the risk of their use to patients.

One justification cited in the literature for the use of diapers with caution is diarrheal intestinal elimination. These, due to the abrasive action on the skin, increase the risk of skin changes, such as pressure lesions, and of incontinence-associated dermatitis. This usually manifests with mild intensity, such as a typical erythematous rash. However, when associated with diarrheal syndrome, the condition often presents rapid and intense evolution. Acutely affects patients on medication or oncological and neurological pathologies, anomalies, genetic syndromes and malnutrition. They can also be found chronically in patients with urofecal incontinence ${ }^{(18)}$.

Therefore, it is necessary to evaluate objective criteria, and even more subjective criteria. The perception of the elderly is not restricted to an object, but to the processes of care that permeate the technique. Communication and interaction are still timid in care relationships in regard to the pursuit of the technique itself. The elderly recognized the diapers as a daily routine such as bathing, hygiene, feeding, dressing change, change of decubitus and medication administration ${ }^{(4)}$. Regardless of age, the hospitalized individual identifies any action or technique as a form of care ${ }^{(17)}$. It is argued that, continents with preserved cognition and mobility use diapers as a means of controlling urinary and intestinal elimination.

Thus, the indication of diapers seems to be supported by the absence of other technologies available to promote urinary elimination or even by the institutional routine adopted. Therefore, comparing the deleterious effects of diaper use varies according to age, degree of dependence, and behavioral factors, may help to deepen these issues, especially if new products are tested.

\section{Study limitations}

The main limitation of this study is the selection of the participants. However, the use of all participants in the study period contributes to the corroboration of the research hypothesis, that there is no homogeneity of indication of the use of diapers for adults and the elderly. However, studies with more substantive and random samples could contribute to more robust analyzes and inferences.

\section{Contributions for the Nursing area}

The need for reflection and systematization of nursing practice contributes to the qualification of care provided. Thus, the analysis of the use of diapers in adults and the elderly can contribute to the reflection of the selection in the criteria of its use in patients, mainly with severe impairment of mobility, severe incontinence and cognitive deficit, besides predicting and minimizing their risks.

\section{CONCLUSION}

The data found contribute to the analysis of the practice of diaper use in adults and the elderly in the hospital, since they expose the unsystematic practice, which exposes patients to risks and complications that weaken professional practice. The fact that the non-association of impaired physical mobility and cognitive impairments to its use, corroborates this inference.

Inserted diapers were also observed, as an extended hospital routine throughout the patients' stay in the setting, disregarding other strategies such as the use of external urinary collectors or early ambulation. This fact can increase patients' dependence and loss of autonomy of decision-making power over their own body and care.

Thus, the "Evaluation Scale for Diapers Use in Adults" (AUFA Scale) is proposed both for indication of use and for monitoring the use of diapers in order to assist in the transposition of this study into nursing practice. 


\section{REFERENCES}

1. Pereira $A B$, Ferreira $B J$. Processo de implantação da política nacional de humanização em hospital público. Trab Educ Saúde[Internet]. 2015[cited 2016 Jun 01];13(1):67-88. Available from: http://www.scielo.br/pdf/tes/v13n1/1981-7746-tes-19817746-sip00024.pdf

2. Sagué-Bravo S, Parra-Cotanda C, Àngel-Solà J, Trenchs-Sainz de la Maza V, Luaces-Cubells C. Presència dels pares durant els procediments invasius als serveis d'urgències pediàtriques: què passa a I'Estate spanyol? Pediatr Catalana[Internet]. 2015[cited 2016 Jun 11];75(1):7-11. Available from: https://dialnet.unirioja.es/servlet/articulo?codigo = 5096910

3. Christini ST, Mazzo A, Rodrigues SRC, Jorge BM, Duarte SJV, Costa MIA. Consequências do uso de fraldas descartáveis em pacientes adultos: implicações para a assistência de enfermagem. Aquichán[Internet]. 2015[cited 2016 May 31];15(1):21-30. Available from: http://saudepublica.bvs.br/pesquisa/resource/pt/lil-749447

4. Alves LAF, Santana RF, Schulz RS. Percepções de idosos sobre a utilização de fraldas durante a hospitalização. Rev Enferm UERJ[Internet] 2014[cited 2016 Jun 09];22(3):371-5. Available from: http://www.e-publicacoes.uerj.br/index.php/enfermagemuerj/ article/view/13727

5. Aquino PA, Melo RP, Lopes MVO, Pinheiro AKB. Analysis of the concept of technology in nursing according to the evolutionary method. Acta Paul Enferm[Internet]. 2010[cited 2016 Jun 01];23(5):690-6. Available from: http://www.scielo.br/pdf/ape/v23n5/ en_17.pdf

6. Roe B, Flanagan L, Jack B, Barrett J, Chung A, Shaw C, et al. Systematic review of the management of incontinence and promotion of continence in older people in care homes: descriptive studies with urinary incontinence as primary focus. J Adv Nurs[Internet]. 2011 [cited 2016 Jun 01];67(2):228-50. Available from: http://www.ncbi.nlm.nih.gov/pubmed/21105895

7. Subak LL, Goode PS, Brubaker L, Kusek JW, Schembri M, Lukacz ES, et al. Urinary incontinence management costs are reduced following Burch or sling surgery for stress incontinence. Am J Obstet Gynecol[Internet]. 2014[cited 2016 Jun 01];211(2):171-3. Available from: https://www.ncbi.nlm.nih.gov/pmc/articles/PMC4349353/

8. Cardoso GB, Silva ALA. O processo de trabalho na enfermagem: articulação das Tecnologias do Cuidado. Rev Enferm UERJ[Internet]. 2010[cited 2016 Jun 03];18(3):451-5. Available from: http://www.facenf.uerj.br/v18n3/v18n3a20.pdf

9. Pereira VS, Santos JYC, Correia GN, Driusso P. Tradução e validação para a língua portuguesa de um questionário para avaliação da gravidade da incontinência urinária. Rev Bras Ginecol Obstet[Internet]. 2011[cited 2016 Jun 08];33(4):182-7. Available from: http://www.scielo.br/pdf/rbgo/v33n4/a06v33n4.pdf

10. Baessa CEB, Meireles VC, Balan MAJ Ocorrência de dermatite associada à incontinência em Pacientes Internados na Unidade de Terapia Intensiva. Rev Estima[Internet]. 2014[cited 2016 Jun 01];12(2):1-8. Available from: http://www.revistaestima.com.br/ index.php/estima/article/view/89

11. Gray M. Beeckman D, Bliss DZ, Fader M, Logan S, Junkin J, et al. Incontinence-associated dermatitis: a comprehensive review and update. J Wound Ostomy Continence Nurs[Internet]. 2012[cited 2016 Jun 01];39(1):61-74. Available from: http://www.ncbi. nlm.nih.gov/pubmed/22193141

12. Locks MOH, Silvia MAS. Uso de fralda geriátrica em hospitais: solução ou problema? Rev Estima[Internet]. 2015 [cited 2016 Jun 01];13(4):27-34. Available from: http://www.revistaestima.com .br/index.php/estima/article/view/102

13. Gray M. Context for practice: medical adhesive-related skin injury, unstageable pressure ulcers, incontinence-associated dermatitis, fluid intake, and overactive bladder. J Wound Ostomy Continence Nurs [Internet]. 2015[cited 2016 Jun 06];42(6):580-1. Available from: http://journals.Iww.com/jwocnonline/Citation/2015/11000/Context_for_Practice_Medical_Adhesive_Related.1.aspx

14. Figueiredo SV, Sousa ACC, Gomes ILV. Children with special health needs and family: implications for Nursing. Rev Bras Enferm[Internet]. 2016[cited 2016 Jun 04];69(1):88-95. Available from: http://www.scielo.br/pdf/reben/v69n1/en_0034-7167reben-69-01-0088.pdf

15. Hein S, Bortoli CFC, Massafera GL. [Factors related to urinary tract infection during pregnancy: integrative review]. J Nurs Health[Internet]. 2016[cited 2016 Jun 01];6(1):83-91. Available from: https://periodicos.ufpel.edu.br/ojs2/index.php/enfermagem/ article/view/5977/5331 Portuguese

16. Alves LAF, Santana RF. Percepções da equipe de enfermagem sobre a utilização de fraldas geriátricas na hospitalização. Cienc Cuid Saude[Internet] 2013[cited 2016 Jun 01];12(1):19-25. Available from: http://www.periodicos.uem.br/ojs/index.php/ CiencCuidSaude/article/view/14814

17. Silva VA, D'Elboux MJ. Factors associated with urinary incontinence in elderly individuals who meet frailty criteria. Texto Contexto Enferm[Internet]. 2012[cited 2016 May 31];21(2):338-47. Available from: http://www.scielo.br/pdf/tce/v21n2/en_a11v21n2.pdf

18. Mathias ALRA, Pitangui ACR, Macedo LF, Dias TG. Incontinência urinária e disfunção sexual no terceiro trimestre gestacional e seis meses após o parto. Rev Fisioter[Internet]. 2015[cited 2016 Jun 01];4(2):21-31. Available from: http://www.fisioterapiaesaudefuncional.ufc.br/ index.php/fisioterapia/article/ view/513

19. Junkin J, Selekof L. Prevalence of incontinence and associated skin injury in the acute care inpatient. J Wound Ostomy Continence Nurs[Internet]. 2007[cited 2016 Jun 01];34(3):260-69. Available from: http://www.ncbi.nlm.nih.gov/pubmed/17505245 
20. Aguiar ESS, Soares MJGO, Caliri MHL, Costa MML, Oliveira SHS. Assessment of functional capacity of the elderly associated with the risk for pressure ulcer. Acta Paul Enferm[Internet]. 2012[cited 2016 Jun 01];25(1):94-100. Available from: http://www.scielo. $\mathrm{br} / \mathrm{pdf} / \mathrm{ape} / \mathrm{v} 25 \mathrm{nspe} 1 / 15 . \mathrm{pdf}$

21. Delarmelindo RCA, Parada CMCGL, Rodrigues RAP, Bocchi SCM. Women's strategies for coping with urinary incontinence. Rev EsC Enferm USP[Internet]. 2013[cited 2016 Jun 01];47(2):296-303. Available from: http://www.scielo.br/pdf/reeusp/v47n2/en_04.pdf

22. Albuquerque MT, Micussi BC, Soares EMM, Lemos TMAM, Brito TNS, Silva JB . Correlação entre as queixas de incontinência urinária de esforço e o pad test de uma hora em mulheres na pós-menopausa. Rev Bras Ginecol Obstet[Internet]. 2011 [cited 2016 Jun 04];33(2):70-4. Available from: http://www.scielo.br/pdf/rbgo/v33n2/v33n2a03.pdf

23. Marques AP, Andrade CLT, Romero DEM, Almeida WS. Internações de idosos por condições sensíveis à atenção primária no Estado do Rio de Janeiro: estudo do impacto da atenção primária na morbidade hospitalar de idosos. Rev Saúde Pública[Internet] 2014[cited 2016 Jun 01];48(5):817-826. Available from: http://www.scielo.br/pdf/rsp/v48n5/pt_0034-8910-rsp-48-5-0817.pdf

24. Drennan VM, Greenwood N, Cole L, Fader M, Grant R, Rait G, et al. Conservative interventions for incontinence in people with dementia or cognitive impairment, living at home: a systematic review. BMC Geriatrics[Internet]. 2012 [cited 2016 Jun 01];12(77):1-10. Available from: http://bmcgeriatr.biomedcentral.com/articles/10.1186/1471-2318-12-77

25. Fürst MCB, Mendonça RR, Rodrigues AO, Matos LL, Pompeo ACL, Bezerra CA. Resultados a longo prazo de um estudo clínico comparando estimulação vaginal isolada com tratamento combinado para mulheres com incontinência urinária de esforço. Einstein (São Paulo) [Internet]. 2014[cited 2016 Jun 08];12(2):168-74. Available from: http://www.scielo.br/pdf/eins/v12n2/16794508-eins-12-2-0168.pdf

26. Beguin D, Malaquin-Pavan E, Guihaire C, Hallet-Lezy AM, Souchon S, Homann V, et al. Improving diaper design to address incontinence associated dermatitis. BMC Geriatrics[Internet]. 2010[cited 2016 Jun 01];10(86):1-10. Available from: http:// bmcgeriatr.biomedcentral.com/articles/10.1186/1471-2318-10-86

27. Sugama J, Sanada H, Shigeta Y, Nakagami G, Konya C. Efficacy of an improved absorbent pad on incontinence-associated dermatitis in older women: cluster randomized controlled trial. BMC Geriatrics[Internet]. 2012[cited 2016 Jun 01];10(86):1-10. Available from: http://bmcgeriatr.biomedcentral.com/articles/10.1186/1471-2318-12-22

28. Black MASD, Gray M, Bliss DZ, Kennedy-Evans KL, Logan S, Baharestani MM, et al. Incontinence-associated dermatitis and intertriginous dermatitis: a consensus. J Wound Ostomy Continence Nurs[Internet]. 2011[cited 2016 Jun 08];38(4):359-70. Available from: http://www.ncbi.nlm.nih.gov/pubmed/21747256

29. Meyer I, Richter HE. Impact of fecal incontinence and its treatment on quality of life in women. Womens Health[Internet]. 2015[cited 2016 Jun 01];11(2):225-38. Available from: http://www.ncbi.nlm.nih.gov/pmc/articles/PMC4394646/

30. Zisberg A, Sinoff G, Gur-Yaish N, Admi H, Shadmi E. In-hospital use of continence aids and new-onset urinary incontinence in adults aged 70 and older. J Am Geriatr Soc[Internet]. 2011[cited 2016 Jun 08];59(6):1099-104. Available from: http://www.ncbi. nlm.nih.gov/pubmed/21649620 